University of Nebraska - Lincoln

DigitalCommons@University of Nebraska - Lincoln

Safety and protective efficacy of INA-inactivated Venezuelan equine encephalitis virus: Implication in vaccine development

\author{
Anuj Sharma \\ Uniformed Services University of the Health Sciences \\ Paridhi Gupta \\ Birla Institute of Technology and Science \\ Pamela J. Glass \\ US Army Medical Research Institute of Infectious Diseases \\ Michael D. Parker \\ US Army Medical Research Institute of Infectious Diseases \\ Radha K. Maheshwari \\ Uniformed Services University of the Health Sciences, rmaheshwari@usuhs.mil
}

Follow this and additional works at: https://digitalcommons.unl.edu/usarmyresearch

Part of the Operations Research, Systems Engineering and Industrial Engineering Commons

Sharma, Anuj; Gupta, Paridhi; Glass, Pamela J.; Parker, Michael D.; and Maheshwari, Radha K., "Safety and protective efficacy of INA-inactivated Venezuelan equine encephalitis virus: Implication in vaccine development" (2011). US Army Research. 153.

https://digitalcommons.unl.edu/usarmyresearch/153

This Article is brought to you for free and open access by the U.S. Department of Defense at DigitalCommons@University of Nebraska - Lincoln. It has been accepted for inclusion in US Army Research by an authorized administrator of DigitalCommons@University of Nebraska - Lincoln. 


\title{
Safety and protective efficacy of INA-inactivated Venezuelan equine encephalitis virus: Implication in vaccine development
}

\author{
Anuj Sharma a , Paridhi Gupta ${ }^{\mathrm{a}, \mathrm{b}}$, Pamela J. Glass ${ }^{\mathrm{c}}$, Michael D. Parker ${ }^{\mathrm{c}}$, Radha K. Maheshwari ${ }^{\mathrm{a}, *}$ \\ a Uniformed Services University of the Health Sciences, Bethesda, MD, USA \\ ${ }^{\mathrm{b}}$ Birla Institute of Technology and Science, Pilani, India \\ ${ }^{c}$ Virology Division, US Army Medical Research Institute of Infectious Diseases, Fort Detrick, MD 21702-5011, United States
}

\section{A R T I C L E I N F O}

\section{Article history:}

Received 10 December 2009

Received in revised form 18 October 2010

Accepted 14 November 2010

Available online 27 November 2010

\section{Keywords:}

VEEV

Inactivation

1,5-Iodonaphthyl-azide

\begin{abstract}
A B S T R A C T
We have previously shown that a hydrophobic alkylating compound, 1,5-iodonaphthyl-azide (INA) can efficiently inactivate the virulent strain of Venezuelan equine encephalitis virus (VEEV), V3000 in vitro. In this study, we have evaluated the safety of INA-inactivated V3000 and V3526 and the protective efficacy of INA-inactivated V3000. INA-inactivated V3000 and V3526 did not cause disease in suckling mice. RNA isolated from the INA-inactivated V3000 and V3526 was also not infectious. Immunization of adult mice with INA-inactivated V3000 induced an anti-VEEV antibody response and protected mice from virulent VEEV challenge. The protective efficacy of INA-inactivated V3000 increased with the use of adjuvants. Results suggest that inactivation of enveloped viruses by INA may occur by two independent mechanisms and the INA-inactivated VEEV elicit a protective antibody response in mice.
\end{abstract}

(C) 2010 Elsevier Ltd. All rights reserved.

\section{Introduction}

Venezuelan equine encephalitis virus (VEEV) is a member of the genus Alphavirus in the family Togaviridae. VEEV causes periodic outbreaks of disease in Latin and South America and is an emerging pathogen [1]. VEEV is highly infectious in aerosol form in mice and non human primates [2,3] and was characterized as a bioweapon [4]. VEEV has been designated a Category B priority pathogen by the National Institute of Allergy and Infectious Disease. VEEV is transmitted by mosquito in nature [5-7] and causes disease of varying severity in horses and humans [8,9].

There is no licensed vaccine available for prophylaxis against VEEV. A live attenuated TC-83 vaccine for VEEV is currently used under investigational new drug (IND) status and is administered to laboratory personnel at risk. However, TC-83 has residual virulence in suckling mice [10] and infection of pregnant mice with TC-83 results in stillbirth and decreased litter size of newborns [11]. TC-83 vaccine is also detrimental for the human fetus [12]. Further limitations of TC-83 vaccine in humans include short-lived immunity and approximately $20 \%$ non-responders [ 13,14$]$. Formalin inactivated TC-83, known as C-84, is used as a booster following immunization with live, attenuated TC-83 vaccine. This vaccine is

\footnotetext{
* Corresponding author at: Centre for Combat Casualty and Life Sustainment Research, Department of Pathology, Uniformed Services University of the Health Sciences, 4301 Jones Bridge Road, Bethesda, MD 20814, United States. Tel.: +1 301295 3394; fax: +1 3012951640 .

E-mail address: rmaheshwari@usuhs.mil (R.K. Maheshwari).
}

also used under IND status, has short-lived immunity and requires frequent boosts $[14,15]$. An attenuated strain, V3526, which has a deletion mutation at the furin cleavage site between the E2 and E3 glycoproteins of the Trinidad donkey strain of VEEV [16] has been extensively evaluated as a VEEV vaccine candidate [17-20]. V3526 has excellent immunogenic activity, but also causes febrile illness and low level neurotropism in non human primates [17,18,21-23]. In phase I clinical trial, V3526 induced a robust immune response; however, a high frequency of fever and a flu-like syndrome were reported which led to the cessation of the development of V3526 as a live attenuated vaccine [24,25].The residual virulence associated with the vaccine candidates has again focused the attention on the inactivated vaccine preparation. We have previously demonstrated that 1,5 iodonaphthyl azide (INA) completely inactivated the virulent strain of VEEV, V3000 in vitro [26]. INA is a hydrophobic photoactive aryl azide that sequesters in the hydrophobic domain of the biological membranes. Irradiation with ultra-violet light results in covalent binding of INA to lipids and proteins embedded in the membrane bilayer $[27,28]$. This results in the inactivation of the membrane proteins without affecting the ectodomain of these proteins that is protruding outside the membrane bilayer $[29,30]$. This mechanism of action of INA was exploited to inactivate other viruses such as HIV, SIV, Ebola and influenza virus [31-33].

In this study, we have evaluated the safety and protective efficacy of INA inactivated-V3000 in mice. We also demonstrate in vitro that INA can efficiently inactivate the live attenuated vaccine strain V3526 of VEEV. These results are important as these establish a proof of concept that INA-inactivated VEEV is safe 
and immunogenic and can be further explored for developing an inactivated VEEV vaccine.

\section{Materials and methods}

\subsection{Virus and animals}

Virus: Molecularly cloned virulent strain of VEEV, V3000 [8] and an attenuated strain, V3526 [34] were used in the present study.

Animals: Swiss CD-1 mice, 5-6 weeks old and 1 day old CD-1 pups and dams were purchased from Charles River Laboratories, Wilmington, MA. Mice were housed in microisolator cages and were provided food and water ad libitum with a $12 \mathrm{~h}$ light/dark cycle. All experiments with V3000 virus strain were carried out in a bio-safety level 3 (BSL-3) facility at Uniformed Services University of The Health Sciences (USUHS), Bethesda, MD. All experiments were conducted in accordance with the Guide for the Care and Use of Laboratory Animals (Committee on Care And Use of Laboratory Animals of The Institute of Laboratory Animal Resources, National Research Council, NIH Publication No. 86-23, revised 1996).

\subsection{Inactivation of VEEV with 1,5 iodonaphthylazide (INA)}

INA was kindly provided by Drs. Robert Blumenthal and Yossef Raviv, National Cancer Research Institute, NIH Frederick, MD under a material transfer agreement. V3526 and V3000 were inactivated with INA as described before [26]. Briefly, purified viral stocks with known titers were suspended in $1 \times$ Dulbecco's Phosphate Buffered Saline (DPBS) (GIBCO, Invitrogen Corporation, Carlsbad, CA) at a protein concentration of $0.5 \mathrm{mg} / \mathrm{ml}$. The preparations were then passed through 30 gauge needle syringe to disperse any viral aggregates in the suspension. Under reduced light conditions, 2-2.5 $\mu \mathrm{l}$ aliquots of $20 \mathrm{mM}$ INA were added to the virus suspension (final concentration $100 \mu \mathrm{M}$ ) along the wall of an ultra clear $1.5 \mathrm{ml}$ microcentrifuge tube (GeneMate, Catalog No. C-3269-1, ISC Bioexpress, Kaysville, UT) followed by immediate vortexing after each addition. Samples were incubated for $20 \mathrm{~min}$ in the dark at room temperature and then centrifuged at $1000 \mathrm{rpm}$ for $1 \mathrm{~min}$ to remove any precipitated INA. The supernatant was transferred to a new tube and $20 \mu \mathrm{l}$ of $1 \mathrm{M}$ glutathione was added at a final concentration of $20 \mu \mathrm{M}$ to quench any unbound INA present in the solution. The virus suspension was vortexed and irradiated using $100 \mathrm{~W}$ mercury UV lamp as described previously [26]. Briefly, the virus suspension was irradiated twice for $90 \mathrm{~s}$ and once for $120 \mathrm{~s}$ followed by vortexing each time. Thereafter full light conditions were used and samples were stored at $-80^{\circ} \mathrm{C}$. Virus titers were back calculated and dilutions were made accordingly for testing the infectivity of INA-inactivated V3526 and INA-inactivated V3000. Therefore, all the doses of INA-inactivated V3526 and INA-inactivated V3000 are plaque forming unit ( $\mathrm{pfu}$ ) equivalent of corresponding virulent VEEV strain.

\subsection{Determination of cytopathic effect (CPE assay)}

Vero cells were plated in 24-well tissue culture plates and infected with V3526 or INA-inactivated V3526 at a multiplicity of infection (MOI) of 1.0 and incubated at $37{ }^{\circ} \mathrm{C}$ and $5 \% \mathrm{CO}_{2}$ incubator. Virus was removed after $1 \mathrm{~h}$ incubation and fresh media was added to the cells after washing once with $1 \times$ DPBS. Cells were observed for cytopathic effect such as rounding and sloughing off from the surface. At $72 \mathrm{~h}$ post-infection (p.i.) cell supernatants were collected from the wells and cells were stained with $0.1 \%$ crystal violet $(\mathrm{CV})$ in $2 \%$ neutral buffered formalin (NBF) solution, for 10 min at room temperature (RT).

\subsection{Virus titration by plaque assay}

Virus titers in the brain of suckling mice were determined by standard plaque assay. Twenty percent (weight/volume) brain samples were prepared by homogenizing brain tissue in $1 \times$ PBS supplemented with $0.1 \%$ bovine serum. Nearly confluent monolayers of Vero cells in $60 \mathrm{~mm}$ culture dishes were incubated with serial dilutions of the samples for $1 \mathrm{~h}$ at $37{ }^{\circ} \mathrm{C}$ and $5 \% \mathrm{CO}_{2}$ incubator and then were rinsed once with $1 \times$ DPBS. Agarose overlay (1\% agarose, $1 \times$ MEM, $6 \%$ newborn calf serum and $0.5 \%$ penicillin-streptomycin) was added to the cells and plates were incubated at $37^{\circ} \mathrm{C}$ and $5 \%$ $\mathrm{CO}_{2}$ incubator. Plaques were visualized and counted at $96 \mathrm{~h}$ p.i by staining the cells with $0.1 \% \mathrm{CV}$ in $2 \% \mathrm{NBF}$ solution for $10 \mathrm{~min}$ at RT.

\subsection{Reverse transcription-PCR (RT-PCR)}

Total RNA was isolated from the brains of intracranial (i.c.) inoculated V3526 (day 4 p.i.) and INA-inactivated V3526 (day 13 p.i.) mice using the TriZol reagent (Invitrogen Inc., Carlsbad, CA) according to manufacturer's protocol. Similarly total RNA was also isolated from Vero cells infected with V3526 and INA-inactivated V3526 $(\mathrm{MOI}=10)$ at $48 \mathrm{~h}$ p.i.

cDNA was made from the total RNA using the SuperScript III First-Strand Synthesis kit (Invitrogen Inc., Carlsbad, CA) according to manufacturer's protocol. Briefly, $1 \mu \mathrm{g}$ of total RNA was mixed with $2.0 \mu \mathrm{l}$ of enzyme mix, $10 \mu \mathrm{l}$ of $2 \times$ buffer and nuclease free water was added to a final reaction volume of $20 \mu l$. The reaction mixture was incubated at RT for 10 min followed by incubation at $50^{\circ} \mathrm{C}$ for $30 \mathrm{~min}$ and $85^{\circ} \mathrm{C}$ for $5 \mathrm{~min}$. Samples were kept on ice for 2 min and $1 \mu \mathrm{l}$ of RNaseH was added followed by an incubation at $37^{\circ} \mathrm{C}$ for $20 \mathrm{~min}$.

V3526 specific PCR for the nonstructural protein 4 (nsP4) gene (virus RNA dependent RNA polymerase) was performed to evaluate the virus infection in vitro. GAPDH served as a house keeping gene. Primer sequences used for nsP4 gene were: Forward- 5'GCTAACAGAAGCAGATACCAG3'; Reverse5'GCAGCCGAATCCAATACGGGC3'. Primer sequences used for GAPDH gene were: Forward- 5'CCATCACCATCTTCCAGGAGCGAG3'; Reverse- 5'CACAGTCTTCTGGGTGGCAGTGAT3'. PCR supermix (Invitrogen Inc., Carlsbad, CA) was used to perform the PCR. Reaction mixture consisted of $45 \mu$ l of PCR supermix, $1 \mu$ l (30 ng) of each primer and $2 \mu \mathrm{l}$ of cDNA. The following PCR cycle was used: initial denaturation at $95^{\circ} \mathrm{C}$ for $3 \mathrm{~min}$, followed by 25 cycles of denaturation at $95^{\circ} \mathrm{C}$ for $30 \mathrm{~s}$, annealing at $62^{\circ} \mathrm{C}$ for $45 \mathrm{~s}$, and extension at $72{ }^{\circ} \mathrm{C}$ for $30 \mathrm{~s}$. A final extension was done at $72{ }^{\circ} \mathrm{C} / 5 \mathrm{~min}$.

\subsection{Evaluation of virus genome for infectivity}

The RNA genome was isolated from $500 \mu$ l of INA-inactivated V3000 and similarly diluted $500 \mu$ l of virulent V3000 using PureLink viral RNA/DNA mini kit (Invitrogen, Carlsbad, CA) as per manufacturer's protocol. RNA was eluted into a final volume of $20 \mu \mathrm{l}$. RNA from two samples was pooled together and quantitated using a Beckman 640 spectrophotometer (Beckman instruments Inc., Columbia, MD, USA). RNA, was transfected into cells using the siPORT Amine transfection reagent (Applied Biosystems/Ambion, Austin, TX) as per manufacturer's protocol. Briefly, the RNA $(100 \mu \mathrm{g})$ was mixed with the transfection reagent and incubated at room temperature for $20 \mathrm{~min}$. Following the incubation, BHK cells suspended in fresh $1 \times$ MEM medium (without antibiotics) were added to the RNA transfection mixture and plated in 8well chamber slides. After $12 \mathrm{~h}$, the transfection reagent mix was removed and replaced with fresh $1 \times$ MEM media (with antibiotics). Cells were incubated for $48 \mathrm{~h}$ and then fixed with chilled $1: 1:$ acetone:methanol solution for $10 \mathrm{~min}$. Slides were then stored at $-20^{\circ} \mathrm{C}$ until stained for VEEV antigen as described below. 

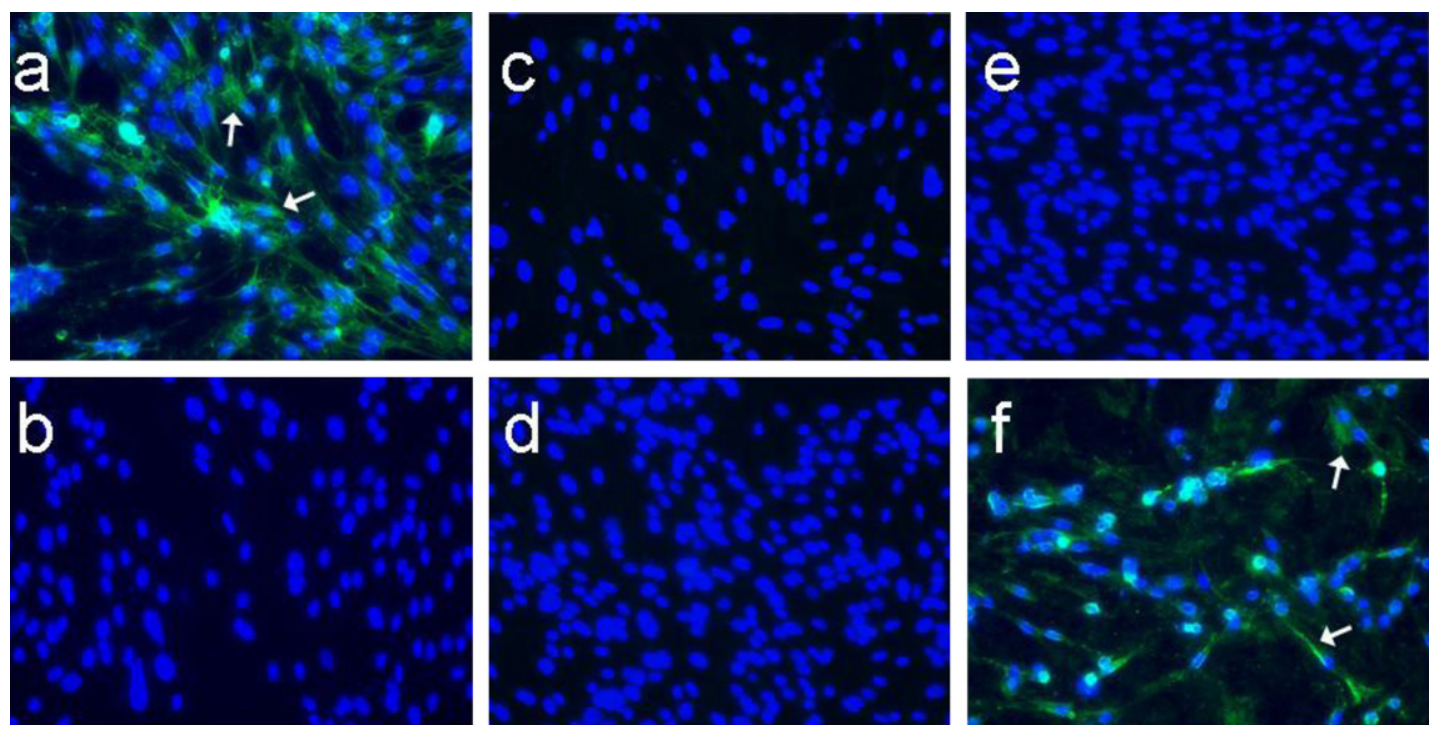

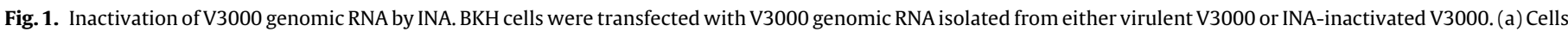

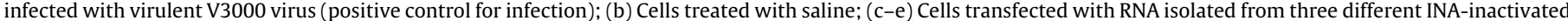

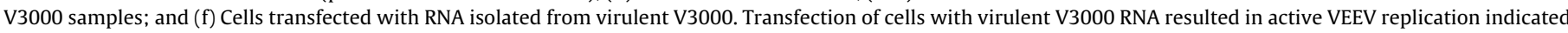

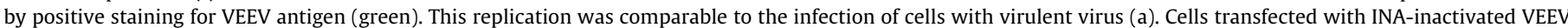

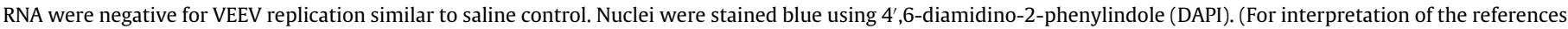
to colour in this figure legend, the reader is referred to the web version of this article.)

\subsection{Immunofluorescence for VEEV antigen}

V3000 (Fig. 1) and V3526 (Fig. 4) antigen specific immunofluorescence was done as described previously [26]. Briefly, slides were rinsed thrice with $1 \times$ PBS for 5 min each and nonspecific binding was blocked using $1 \%$ BSA for $1 \mathrm{~h}$ at room temperature. Excess BSA was removed and slides were incubated with 1:1000 diluted polyclonal rabbit anti-VEEV antibody (kindly provided by Dr. Franziska B. Grieder, USUHS, Bethesda, MD) for $1 \mathrm{~h}$ at $37^{\circ} \mathrm{C}$. Slides were then rinsed thrice with $1 \times$ PBS for 5 min each and incubated with FITCconjugated goat anti-rabbit $\operatorname{IgG}(1: 1000)$ for $30 \mathrm{~min}$ at $37^{\circ} \mathrm{C}$. This antibody recognizes both V3526 and V3000 strains of VEEV. Slides were washed thrice with $1 \times$ PBS for 5 min each, mounted with vectashield mounting medium containing DAPI (Vector laboratories, Inc., Burlingame, CA), and were observed under fluorescence microscope.

\subsection{Residual virulence evaluation in suckling mice}

For the entire in vivo study, stock virus suspension was diluted to desired working suspension in $1 \times$ DPBS.

Suckling mice study with V3000 and V3526: Five day old mice were infected intraperitoneally (i.p.) with 10,000 pfu of virulent V3000 or INA-inactivated V3000 ( $n=9$ or $n=10$, respectively) in a final volume of $20 \mu \mathrm{l}$. Nine day old mice were infected intracranially (i.c.) with 10,000 pfu of INA-inactivated V3000 $(n=10)$ or virulent V3000 $(n=9)$ in a final volume of $20 \mu \mathrm{l}$. Three days old mice were infected i.c. with 10,000 pfu of V3526 $(n=8)$ or INAinactivated V3526 $(n=10)$ in a final volume of $20 \mu$ l. Control mice $(n=2)$ were similarly injected with $1 \times$ phosphate buffered saline (PBS). Animals were observed for a period of 2 weeks for the development of any clinical signs of disease and infection. Brain tissues were collected from all mice at the end of two weeks observation period and were stored at $-80^{\circ} \mathrm{C}$.

\subsection{Immunization and protection study}

Three separate immunization studies were undertaken. Five to six weeks old male CD-1 mice were injected intraperitoneally with the INA-inactivated V3000 on day zero. At 7th day post last vaccination, mice were challenged with virulent V3000 virus. Mice were anesthetized using inhalation anesthesia, isofluorane using a "drop jar method" as described before [35] and 1000 pfu of virulent V3000 were inoculated in the rear footpad of each mouse.

First study: $n=6$. Booster doses were given at day 7 post first immunization (pfi) and day 14 pfi. Immunization consisted of 10,000 INA-inactivated pfu of V3000. Six age-matched nonvaccinated mice were included as control. On the day $21 \mathrm{pfi}$, blood was collected by tail vein nick and serum was isolated. Mice were then challenged with virulent V3000 strain of VEEV.

Second study: $n=10$ per group. Booster doses were given at days 7, 14 and 21 pfi. First two booster doses consisted of 10,000 pfu of INA-inactivated V3000 and the third booster dose consisted of 50,000 pfu of INA-inactivated V3000. On the day 28 pfi blood was collected by tail vein nick and serum was isolated. On day 29 pfi mice were challenged with virulent $\mathrm{V} 3000$. Three individual groups were examined: (1) INA-inactivated V3000 alone. Mice were immunized with the INA-inactivated V3000 formulation alone for all four immunizations. (2) INA-inactivated V3000 with Alhydrogel as adjuvant. Alhydrogel ${ }^{\circledR}$ (Brenntag Biosector, Fredeikssund, Denmark) was first diluted to a working suspension containing $2 \mathrm{mg} / \mathrm{ml}$ of aluminum in $1 \times$ DPBS. INA-inactivated V3000 was mixed with diluted Alhydrogel in equal volumes. This mixture was then continuously vortexed for $2 \mathrm{~h}$ at room temperature. Animals were given four immunizations of this INA-inactivated V3000-Alhydrogel formulation. (3) INA-inactivated VEEV with Complete Freund's adjuvant (CFA). INA-inactivated V3000 was mixed with the equal volume of CFA just prior to immunization. Only the first immunization was given with the INA-inactivated V3000-CFA formulation and the subsequent three immunizations contained only INA-inactivated V3000. Ten age-matched non-vaccinated mice were included as controls.

Third-study: Nineteen mice were immunized with 50,000 pfu at day zero followed by two booster immunizations with $50,000 \mathrm{pfu}$ each at day 7 and day 14 pfi. Five age-matched non-vaccinated mice were included as control. On day 21 pfi, mice were challenged with virulent V3000 strain of VEEV. 
In all the three studies mice were monitored for the clinical symptoms of disease and mortality for 14 days after challenge with virulent virus.

\subsection{Enzyme-linked immunosorbent assay for detecting anti-VEEV antibody in serum}

Blood was incubated on ice for $30 \mathrm{~min}$ and then centrifuged at high speed for $30 \mathrm{~min}$. The aqueous layer of serum was then collected and immediately stored at $-80^{\circ} \mathrm{C}$. For enzyme-linked immunosorbent assay (ELISA), 96 well Immulon 4HBX ultra-high binding polystyrene microtiter plates (Thermo Electron Corp., Milford, MA) were coated with $5 \mu \mathrm{g}$ of virulent V3000 strain of VEEV per well in $50 \mu \mathrm{l}$ volume at $4{ }^{\circ} \mathrm{C}$ overnight. The virus suspension was then removed and plates were blocked with $1 \%$ Bovine Serum Albu$\min (\mathrm{BSA})(50 \mu \mathrm{l} /$ well $)$ at $4{ }^{\circ} \mathrm{C}$ overnight. Blocking agent was then removed and $50 \mu$ l serially diluted serum $(1: 50,1: 250,1: 625$ and $1: 1250)$ was added to wells in triplicates. Plates were then incubated for $4 \mathrm{~h}$ at $37^{\circ} \mathrm{C}$ followed by two washes, first with $0.05 \%$ Tween 20 in $1 \times$ PBS and then with distilled water. An aliquot $(50 \mu \mathrm{l})$ of alkaline phosphatase conjugated goat anti-mouse IgG (secondary antibody) (1:1000) was added to each well and incubated at $37^{\circ} \mathrm{C}$ for $1 \mathrm{~h}$. Plates were then washed twice first with $0.05 \%$ Tween 20 in $1 \times$ PBS and then with distilled water. Phosphatase substrate (Sigma-Aldrich, St. Louis, MO) was then added ( $50 \mu \mathrm{l} /$ well of $5 \mathrm{mg} / \mathrm{ml}$ ) and color was allowed to develop for $10 \mathrm{~min}$ at $37^{\circ} \mathrm{C}$. Plates were read at $405 \mathrm{~nm}$ wavelength using ELISA reader (Bio-Rad Laboratories, Inc., Hercules, CA 94547).

\section{Results and discussion}

In our previous study [26] we demonstrated that V3000 virus, rescued from a cDNA of VEEV [8], can be completely inactivated with INA in vitro. In this study we tested the safety and protective efficacy of INA-inactivated V3000 in mice. To test the residual virulence that may be associated with the INA-inactivated VEEV, suckling mice were inoculated with INA-inactivated V3000 and were observed for disease morbidity. Suckling mice are immunologically immature and fail to or induce inadequate antibody response to infection [36]. The immature neurons are also more susceptible to virus induced apoptosis [37]. Therefore, these mice should be sensitive to any residual virulence that may be associated with inactivated preparations of virus. None of the suckling mice infected with INA-inactivated V3000 (i.p. or i.c.) showed any clinical sign of disease and survived the two week observational period (Table 1). Mice that received V3000 succumbed to the virus infection within $48 \mathrm{~h}$ p.i. The positive sense RNA genome of alphaviruses is infectious and when transfected into sensitive cell lines results in the generation of live virus particles [38,39].
Table 1

Safety evaluation in suckling mice.

\begin{tabular}{lcl}
\hline Group(s) & Percent survival & Mice died/total mice \\
\hline V3000 (i.p.) & 0 & $10 / 10$ \\
V3000 + INA + IRRAD (i.p.) & 100 & $0 / 9$ \\
V3000 (i.c.) & 0 & $9 / 9$ \\
V3000 + INA + IRRAD (i.c.) & 100 & $0 / 10$ \\
V3526 (i.c.) & 0 & $8 / 8$ \\
V3526 + INA + IRRAD (i.c.) & 10 & $0 / 10$ \\
\hline
\end{tabular}

Suckling mice were infected with virulent and INA-inactivated viruses as described in Section 2. All the animals that received INA-inactivated virus (either V3000 or V3526) survived and developed normally. As expected, animals that received V3000 by either route (i.c. or i.p.) succumbed to the infection with in $48 \mathrm{~h}$ p.i. All the animals that received virulent V3526 either succumbed to the infection or were humanely euthanized due to the severe disease morbidity at $96 \mathrm{~h}$ p.i.

BHK cells were transfected with RNA isolated from INA-inactivated V3000. Immunofluorescence staining for VEEV antigen showed that RNA isolated from INA-inactivated V3000 was non-infectious. Positive VEEV staining was observed in the cells that were transfected with RNA isolated from virulent V3000. The staining was similar to that of V3000 virus infection. The cells that were transfected with the RNA from INA-inactivated V3000 did not show any staining for VEEV antigen and were similar to that of negative controls (Fig. 1). These results indicate that INA may have another mechanism of virus inactivation independent of protein binding. This is a novel finding as INA was only known to inactivate virus by binding to the viral proteins $[31,40]$. Since VEEV RNA is infectious, its inactivation by INA may further reduce the residual virulence that may be associated with infectious RNA of otherwise inactivated VEEV. Incompletely inactivated VEEV vaccine was believed to be responsible for some of the outbreaks of VEEV [1]. Thus inactivation of VEEV RNA by INA may provide another level of protection against incomplete inactivation seen with other inactivation methods. Further studies are in progress to evaluate interaction of INA with viral RNA.

To test the efficacy of INA-inactivated VEEV to induce protective antibody response a proof of concept study with INAinactivated V3000 was undertaken. Mice were immunized with INA-inactivated V3000 as described in Section 2. In the first study, 3 doses of 10,000 pfu equivalents of INA-inactivated V3000 induced a $60 \%$ protective response in mice (data not shown). To evaluate if additional immunization and use of adjuvant increase the protection efficacy we gave an additional immunization dose and used Alhydrogel and CFA adjuvant in the second study. Alhydrogel is an approved adjuvant for human use and has been shown to increase the protection in gamma irradiated V3526 immunized mice [41]. CFA is also a potent adjuvant and was used to compare the response to Alhydrogel and to determine if use of adjuvant increases the protective efficacy. INA-inactivated V3000 alone still

Table 2

Immunization with INA-inactivated VEEV protected mice from virulent VEEV challenge.

\begin{tabular}{|c|c|c|}
\hline Group(s) & $\begin{array}{l}\text { Vaccine study }(10,000 \mathrm{pfu}) \text { protection }(\%) \\
\text { (total died/total mice) }\end{array}$ & $\begin{array}{l}\text { Vaccine study (50,000 pfu) protection (\%) } \\
\text { (total died/total mice) }\end{array}$ \\
\hline Non-vaccinated & $0^{\mathrm{a}}(10 / 10)^{\mathrm{b}}$ & $0(5 / 5)$ \\
\hline Inactivated V3000' & $60(4 / 10)$ & $78.94(4 / 19)$ \\
\hline Inactivated V3000+CFA d & $80(2 / 10)$ & - \\
\hline Inactivated V3000+ Alhydrogel $^{\mathrm{e}}$ & $90(1 / 10)$ & - \\
\hline
\end{tabular}

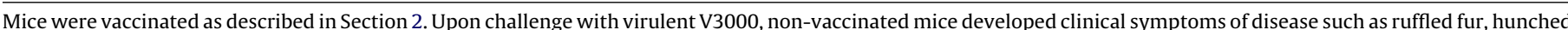

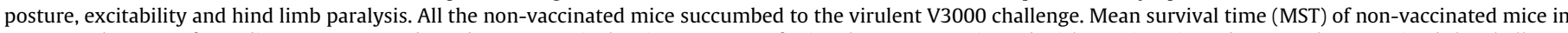

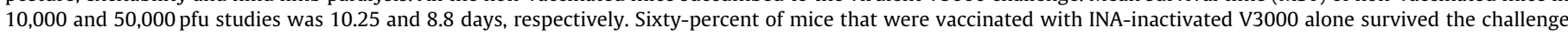
with virulent virus. Protection with INA-inactivated V3000 vaccine increased with the use of CFA and Alhydrogel to $80 \%$ and $90 \%$, respectively.

a Percent protection.

b Total died/total number.

c V3000 inactivated with $100 \mu \mathrm{M}$ dose of INA in combination with irradiation.

d Complete Freund's adjuvant.

e Aluminum hydroxide containing $2 \mathrm{mg} / \mathrm{ml}$ of aluminum. 
conferred $60 \%$ protection. In, adjuvanted INA-inactivated V3000 groups the protective efficacy increased to $80 \%$ and $90 \%$ with the use of CFA and Alhydrogel, respectively (Table 2). Since increasing the number of immunizations did not affect the protective efficacy of INA-inactivated V3000 alone, we next tested the effect of increasing the immunization dose of INA-inactivated V3000 to 50,000 pfu equivalents. Protection against virulent V3000 increased to $80 \%$ from $60 \%$ as was seen with 10,000 pfu equivalent dosages. As expected, all the non-immunized mice succumbed to challenge with virulent VEEV (Table 2). None of the mice inoculated with the INA-inactivated V3000 in the above three studies showed any clinical symptoms of disease such as hunched back, anxiety, loss of appetite and hind limb paralysis. Though further experiments are needed to establish complete protective dose of INA-inactivated V3000, these experiments demonstrate the protective efficacy of INA-inactivated V3000. The serum antibody response was variable in the group vaccinated with INA-inactivated V3000 alone, some mice had an antibody titer of $>\log _{10} 2.1$ and some mice had titers $<\log _{10} 2.0$. Use of CFA resulted in a more uniform antibody response compared to the INA-inactivated V3000 alone group that was approximately $\log _{10} 2.1$. Use of Alhydrogel resulted in a uniformly higher antibody response $(p=0.00036)$ compared to the INA-inactivated V3000 alone group (Fig. 2). Adjuvants such as CpG and Alhydrogel have been shown to enhance the antibody titers and protection in mice immunized with gamma irradiated V3526 [41]. These results are similar to those demonstrated by others with influenza and Ebola viruses where INA-inactivated viruses induced protective antibody response to respective viruses [32,33].

We also demonstrate in vitro that INA can efficiently inactivate the live attenuated vaccine strain V3526 of VEEV. Live attenuated V3526 has shown excellent protective efficacy in animal models $[17,18]$ and robust immune response in phase I clinical trial [25]. However, its development as a live attenuated vaccine was halted due to a flu-like syndrome and fever in the recipients $[24,25]$. Therefore, it will be desirable to inactivate V3526 in a way that conserves its immunogenicity to generate a safer vaccine candidate without any residual virulence. Since INA inactivates virulent VEEV strain, V3000 [26] and has been shown to conserve

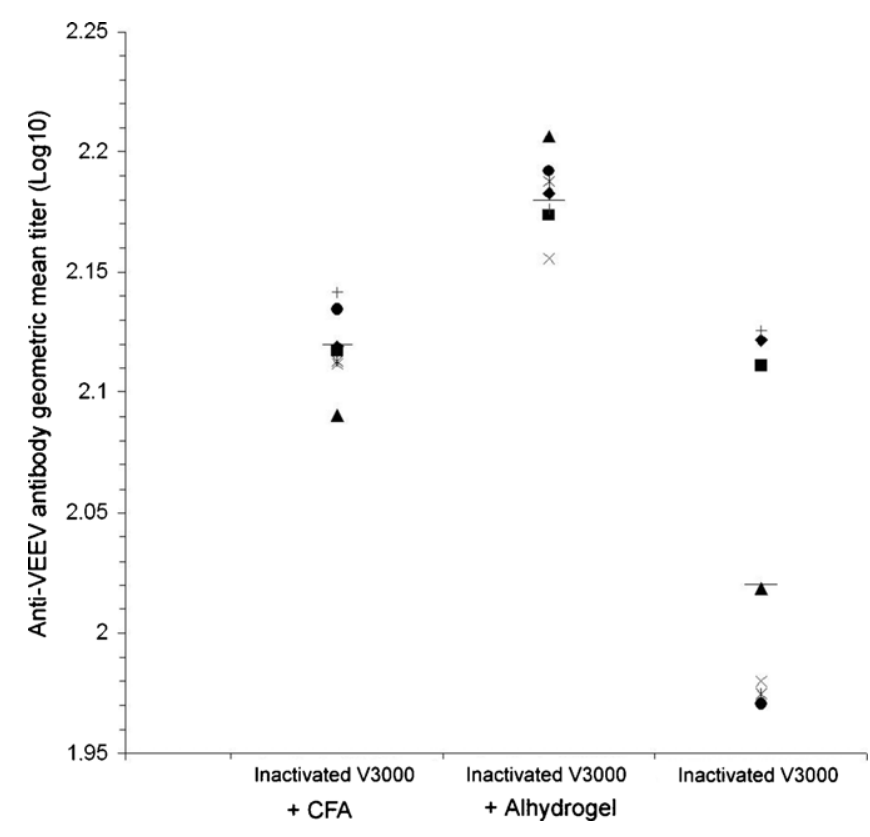

Fig. 2. Serum antibody titer in mice vaccinated with INA-inactivated V3000. Serum anti-VEEV antibody titer was evaluated using ELISA as described in Section 2. Vaccination with INA-inactivated V3000 alone resulted in variable anti-VEEV antibody titer within the group. Incorporation of CFA adjuvant in the vaccine resulted in a more uniform anti-VEEV antibody titer within the group $(p=0.021)$. Use of Alhydrogel as an adjuvant in the vaccine resulted in consistently higher anti-VEEV antibody titer within the group $(p=0.00036)$. Symbols in each group indicate antibody titer in individual mice.

the virion surface epitopes [31-33] we used INA to inactivate V3526. A $100 \mu \mathrm{M}$ dose of INA completely inactivated the live V3526. INA-inactivated V3526 did not induce cytopathic effect (CPE) or cell death in Vero cells (Fig. 3A). Treatment of cells with free INA showed no toxicity up to $200 \mu \mathrm{M}$ dosages ruling out any cell death due to free INA in the solution (Supplementary Fig. 1). No virus replication was detected either in the supernatant of
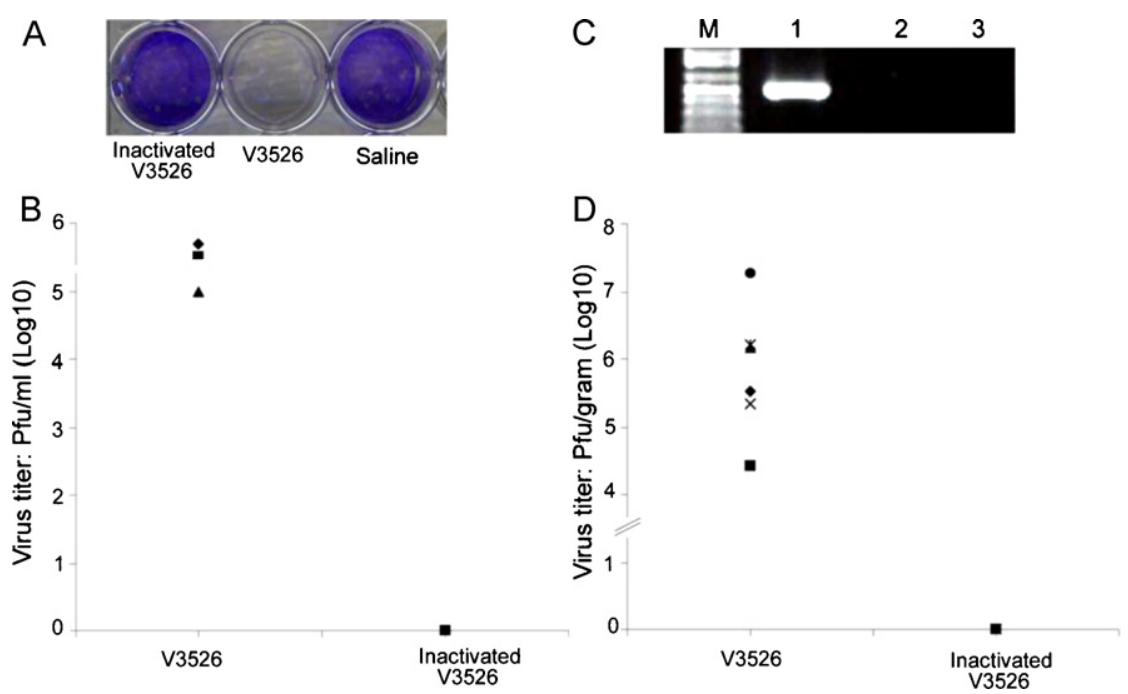

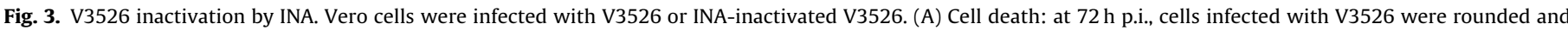

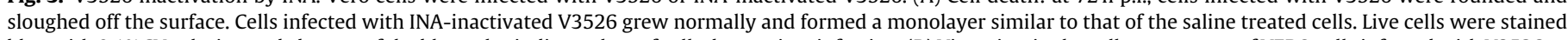

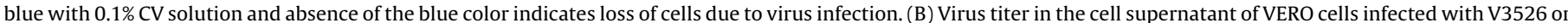

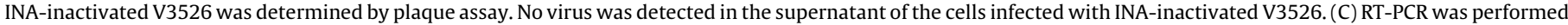

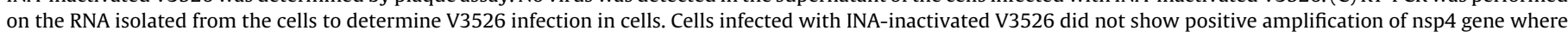

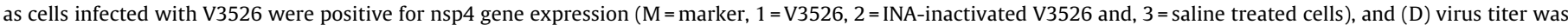

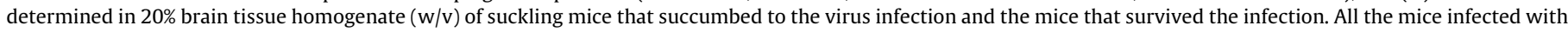

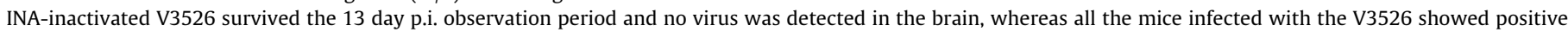
virus replication. Each symbol in B and $C$ represent virus titer in individual sample or animal, respectively. 

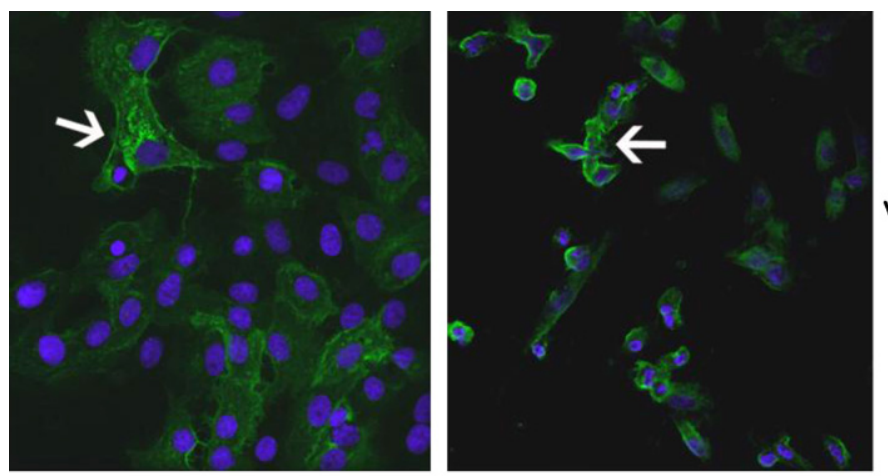

V3526
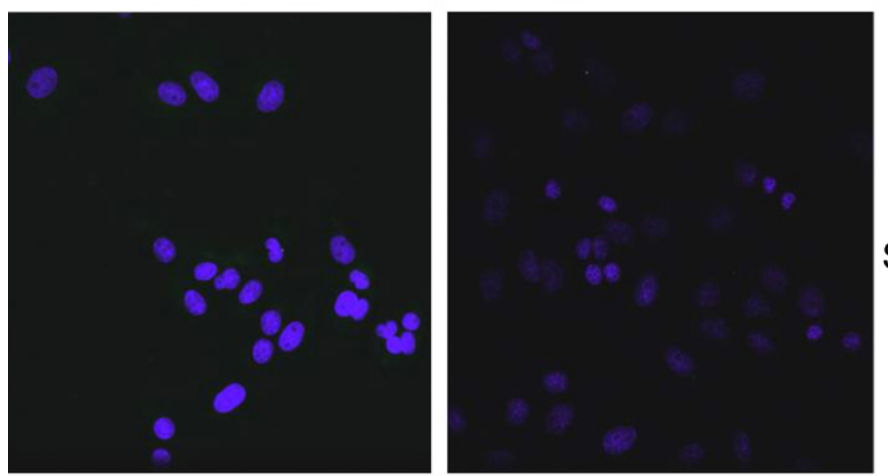

Saline
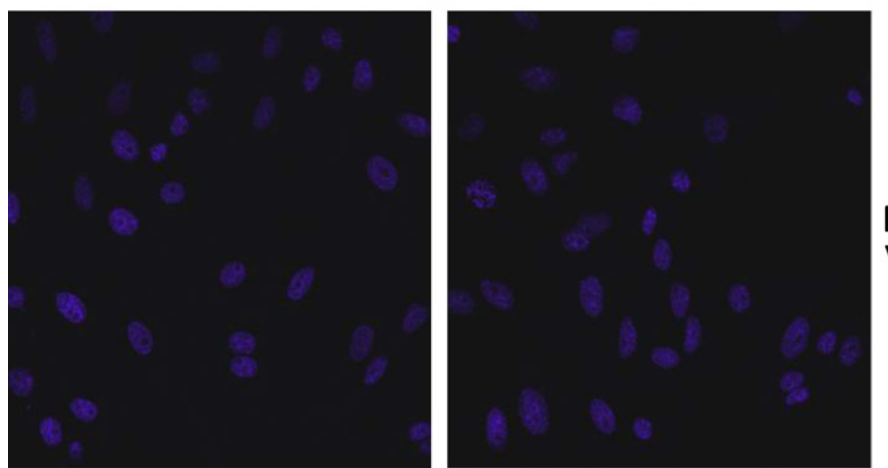

48 hr p.i.

\section{INA-inactivated}

V3526

$36 \mathrm{hr}$ p.i.

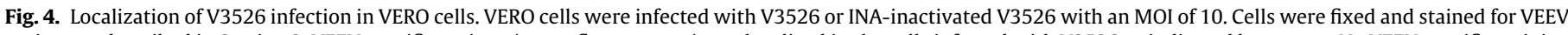

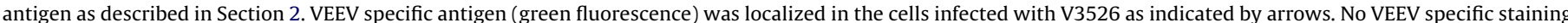

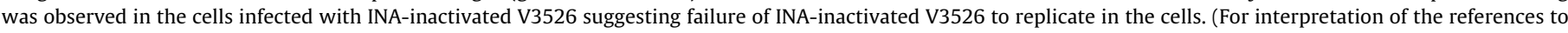
colour in this figure legend, the reader is referred to the web version of this article.)

or in the cells infected with INA-inactivated V3526 (Fig. 3B and C). Immunofluorescence staining for V3526 antigen in the cells infected with the INA-inactivated V3526 also did not show any VEEV specific staining (Fig. 4). These results corroborated our previous findings with V3000 strain of VEEV [26] and also with other reports of inactivation of influenza, Ebola, HIV and SIV viruses by INA [31-33]. Further RNA isolated from the INA-inactivated V3526 did not show any infectivity (Supplementary Fig. 2). We also tested the INA-inactivated V3526 for any residual virulence in suckling mice. Suckling mice inoculated i.c. with V3526 developed the disease and either succumbed to the infection within 48-96 h p.i. or were humanely euthanized at $96 \mathrm{~h}$ p.i. due to disease morbidity such as stunted growth, slow breathing rate and little to no movement (Table 1). None of the mice which received INA-inactivated V3526 showed any clinical symptoms of disease such as, hunched posture, stunted growth, lethargic or paralysis and grew similar to that of the control mice. Further studies are in progress to evaluate the protective efficacy of INA-inactivated V3526.

These results have significant implications as INA-inactivated VEEV overcomes the residual virulence reported with the vaccine strains for VEEV, i.e. TC-83, V3526 without potentially degenerating the surface antigenic epitopes as seen with formalin inactivation. INA-inactivation also appears to render the positive sense RNA genome non-infectious thereby inactivating by two independent mechanisms of inactivation and thus has an added advantage over the existing methods of inactivation. VEEV is endemic in the Central and South America and has long been considered a potential biothreat agent. Current IND TC-83 vaccine has limited use due to $20 \%$ non responder rate and poor protection from other subtypes of VEEV. Therefore, there remains an urgent need for an effective vaccine for immunization against VEEV. These results show that INA-inactivated VEEV is safe and can protect against virulent VEEV challenge in mice. Therefore, this strategy of virus inactivation may prove beneficial for the production of safe and immunogenic inactivated alphavirus vaccines.

\section{Acknowledgements}

This work was supported in part by Grants from the Defense Threat Reduction Agency and USAMRIID contract No. G174QH. The 
opinions or assertions contained herein are the scientific views of the authors and should not be construed as official or necessarily reflecting the views or policies of the Uniformed Services University of the Health Sciences or the Department of Defense, USA.

\section{Appendix A. Supplementary data}

Supplementary data associated with this article can be found, in the online version, at doi:10.1016/j.vaccine.2010.11.033.

\section{References}

[1] Weaver SC, Ferro C, Barrera R, Boshell J, Navarro JC. Venezuelan equine encephalitis. Annu Rev Entomol 2004;49:141-74.

[2] Steele KE, Davis KJ, Stephan K, Kell W, Vogel P, Hart MK. Comparative neurovirulence and tissue tropism of wild-type and attenuated strains of Venezuelan equine encephalitis virus administered by aerosol in $\mathrm{C} 3 \mathrm{H} / \mathrm{HeN}$ and $\mathrm{BALB} / \mathrm{c}$ mice. Vet Pathol 1998;35(September (5)):386-97.

[3] Koterski J, Twenhafel N, Porter A, Reed DS, Martino-Catt S, Sobral B, et al. Gene expression profiling of nonhuman primates exposed to aerosolized Venezuelan equine encephalitis virus. FEMS Immunol Med Microbiol 2007;51(December (3)):462-72.

[4] Hawley RJ, Eitzen Jr EM. Biological weapons-a primer for microbiologists. Annu Rev Microbiol 2001;55:235-53.

[5] Smith DR, Aguilar PV, Coffey LL, Gromowski GD, Wang E, Weaver SC. Venezuelan equine encephalitis virus transmission and effect on pathogenesis. Emerg Infect Dis 2006;12(August (8)):1190-6.

[6] Weaver SC. Host range, amplification and arboviral disease emergence. Arch Virol Suppl 2005; 19:33-44.

[7] Ferro C, Boshell J, Moncayo AC, Gonzalez M, Ahumada ML, Kang W, et al. Natural enzootic vectors of Venezuelan equine encephalitis virus, Magdalena Valley, Colombia. Emerg Infect Dis 2003;9(January (1)):49-54.

[8] Bowen GS. Experimental infection of North American mammals with epidemic Venezuelan encephalitis virus. Am J Trop Med Hyg 1976;25(November (6)):891-9.

[9] Steele KE, Twenhafel NA. Review Paper: Pathology of Animal Models of Alphavirus Encephalitis. Vet Pathol 2010;47(5):790-805.

[10] Paessler S, Fayzulin RZ, Anishchenko M, Greene IP, Weaver SC, Frolov I. Recombinant sindbis/Venezuelan equine encephalitis virus is highly attenuated and immunogenic. J Virol 2003;77(September (17)):9278-86.

[11] Spertzel RO, Crabbs CL, Vaughn RE. Transplacental transmission of Venezuelan equine encephalomyelitis virus in mice. Infect Immun 1972;6(September (3)):339-43.

[12] Casamassima AC, Hess LW, Marty A. TC-83 Venezuelan equine encephalitis vaccine exposure during pregnancy. Teratology 1987;36(December (3)):287-9.

[13] Alevizatos AC, McKinney RW, Feigin RD. Live, attenuated Venezuelan equine encephalomyelitis virus vaccine. I. Clinical effects in man. Am J Trop Med Hyg 1967;16(November (6)):762-8.

[14] Pittman PR, Makuch RS, Mangiafico JA, Cannon TL, Gibbs PH, Peters CJ. Longterm duration of detectable neutralizing antibodies after administration of liveattenuated VEE vaccine and following booster vaccination with inactivated VEE vaccine. Vaccine 1996;14(March (4)):337-43.

[15] Engler RJ, Mangiafico JA, Jahrling P, Ksiazek TG, Pedrotti-Krueger M, Peters CJ. Venezuelan equine encephalitis-specific immunoglobulin responses: live attenuated TC-83 versus inactivated C-84 vaccine. J Med Virol 1992;38(December (4)):305-10.

[16] Davis NL, Brown KW, Greenwald GF, Zajac AJ, Zacny VL, Smith JF, et al. Attenuated mutants of Venezuelan equine encephalitis virus containing lethal mutations in the PE2 cleavage signal combined with a second-site suppressor mutation in E1. Virology 1995;212(September (1)):102-10.

[17] Rao V, Hinz ME, Roberts BA, Fine D. Environmental hazard assessment of Venezuelan equine encephalitis virus vaccine candidate strain V3526. Vaccine 2004;22(June (20)):2667-73.

[18] Rao V, Hinz ME, Roberts BA, Fine D. Toxicity assessment of Venezuelan Equine Encephalitis virus vaccine candidate strain V3526. Vaccine 2006;24(March (10)):1710-5.

[19] Fine DL, Jenkins E, Martin SS, Glass P, Parker MD, Grimm B. A multisystem approach for development and evaluation of inactivated vaccines for Venezuelan equine encephalitis virus (VEEV). J Virol Methods 2009;(November).
[20] Hart MK, Caswell-Stephan K, Bakken R, Tammariello R, Pratt W, Davis N, et al. Improved mucosal protection against Venezuelan equine encephalitis virus is induced by the molecularly defined, live-attenuated V3526 vaccine candidate. Vaccine 2000;18(July (26)):3067-75.

[21] Pratt WD, Davis NL, Johnston RE, Smith JF. Genetically engineered, live attenuated vaccines for Venezuelan equine encephalitis: testing in animal models. Vaccine 2003;21(September (25-26)):3854-62.

[22] Reed DS, Lind CM, Lackemeyer MG, Sullivan LJ, Pratt WD, Parker MD. Genetically engineered, live, attenuated vaccines protect nonhuman primates against aerosol challenge with a virulent IE strain of Venezuelan equine encephalitis virus. Vaccine 2005;23(May (24)):3139-47.

[23] Fine DL, Roberts BA, Terpening SJ, Mott J, Vasconcelos D, House RV. Neurovirulence evaluation of Venezuelan equine encephalitis (VEE) vaccine candidate V3526 in nonhuman primates. Vaccine 2008;26(June (27-28)):3497-506.

[24] Martin SS, Bakken RR, Lind CM, Reed DS, Price JL, Koeller CA, et al. Telemetric analysis to detect febrile responses in mice following vaccination with a liveattenuated virus vaccine. Vaccine 2009;27(November (49)):6814-23.

[25] Holley P, Fine DL, Terpening SJ, Mallory CJ, Main CA, Snow DM, et al.Safety of an attenuated Venezuelan equine encephalitis virus (VEEV) vaccine in humans. 2008.

[26] Sharma A, Raviv Y, Puri A, Viard M, Blumenthal R, Maheshwari RK. Complete inactivation of Venezuelan equine encephalitis virus by 1,5 -iodonaphthylazide. Biochem Biophys Res Commun 2007;358(June (2)):392-8.

[27] Kahane I, Gitler C. Red cell membrane glycophorin labeling from within the lipid bilayer. Science 1978;201(July (4353)):351-2.

[28] Raviv Y, Salomon Y, Gitler C, Bercovici T. Selective labeling of proteins in biological systems by photosensitization of 5 -iodonaphthalene-1-azide. Proc Natl Acad Sci U S A 1987;84(September (17)):6103-7.

[29] Bercovici T, Gitler C. 5-[125I]Iodonaphthyl azide, a reagent to determine the penetration of proteins into the lipid bilayer of biological membranes. Biochemistry 1978;17(April (8)):1484-9.

[30] Raviv Y, Bercovici T, Gitler C, Salomon Y. Selective photoinduced uncoupling of the response of adenylate cyclase to gonadotropins by 5-iodonaphthyl 1-azide. Biochemistry 1984;23(January (3)):503-8.

[31] Raviv Y, Viard M, Bess Jr JW, Chertova E, Blumenthal R. Inactivation of retroviruses with preservation of structural integrity by targeting the hydrophobic domain of the viral envelope. J Virol 2005;79(October (19)):12394-400.

[32] Warfield KL, Swenson DL, Olinger GG, Kalina WV, Viard M, Aitichou M, et al. Ebola virus inactivation with preservation of antigenic and structural integrity by a photoinducible alkylating agent. J Infect Dis 2007;196(November (Suppl. 2)):S276-83.

[33] Raviv Y, Blumenthal R, Tompkins SM, Humberd J, Hogan RJ, Viard M. Hydrophobic inactivation of influenza viruses confers preservation of viral structure with enhanced immunogenicity. J Virol 2008;82(May (9)):4612-9.

[34] Turell MJ, Parker MD. Protection of hamsters by Venezuelan equine encephalitis virus candidate vaccine V3526 against lethal challenge by mosquito bite and intraperitoneal injection. Am J Trop Med Hyg 2008;78(February (2)):328-32.

[35] Sharma A, Maheshwari RK. Oligonucleotide array analysis of Toll-like receptors and associated signalling genes in Venezuelan equine encephalitis virusinfected mouse brain. J Gen Virol 2009;90(August (Pt 8)):1836-47.

[36] Overman JR. Antibody response of suckling mice to mumps virus. I. Immune response following immunization with mumps virus vaccine. J Immunol 1954;73(October (4)):244-8.

[37] Griffin DE, Levine B, Tyor WR, Tucker PC, Hardwick JM. Age-dependent susceptibility to fatal encephalitis: alphavirus infection of neurons. Arch Virol Suppl 1994;9:31-9.

[38] Pushko P, Bray M, Ludwig GV, Parker M, Schmaljohn A, Sanchez A, et al. Recombinant RNA replicons derived from attenuated Venezuelan equine encephalitis virus protect guinea pigs and mice from Ebola hemorrhagic fever virus. Vaccine 2000;19(August (1)):142-53.

[39] Hernandez R, Sinodis C, Brown DT. Sindbis virus: propagation, quantification, and storage. Curr Protoc Microbiol 2005;(October). Chapter 15: Unit $15 \mathrm{~B} 1$.

[40] Viard M, Ablan SD, Zhou M, Veenstra TD, Freed EO, Raviv Y, et al. Photoinduced reactivity of the HIV-1 envelope glycoprotein with a membrane-embedded probe reveals insertion of portions of the HIV-1 Gp41 cytoplasmic tail into the viral membrane. Biochemistry 2008;47(February (7)):1977-83.

[41] Martin SS, Bakken RR, Lind CM, Garcia P, Jenkins E, Glass PJ, et al. Comparison of the immunological responses and efficacy of gamma-irradiated V3526 vaccine formulations against subcutaneous and aerosol challenge with Venezuelan equine encephalitis virus subtype IAB. Vaccine 2010;28(January (4)): $1031-40$. 